矢野 茂敏, 秀 拓一郎, 篠島 直樹, 倉津 純一

熊本大学大学院生命科学研究部脳神経外科分野

\title{
Usefulness of Indocyanine Green Fluorescence Endoscopy in Endo- scopic Skull Base Surgery
}

\author{
Shigetoshi Yano, M.D., Takuichiro Hide, M.D., Naoki Shinojima, M.D., and Jun-ichi Kuratsu, M.D. \\ Department of Neurosurgery, Faculty of Life Sciences, Kumamoto University Graduate School
}

Ongoing developments in endoscopic surgery continue to provide further indications for treating various skull base lesions. Recently, the usefulness of photodynamic diagnosis has been recognized in brain tumor resection and vascular surgery. Although those modalities give operators additional information such as tumor extension or vascular patency under microscope, its efficacy in endoscopic surgery is not confirmed. The authors applied the indocyanine green (ICG) fluorescence endoscopy in endoscopic endonasal skull base surgery and successfully recorded ICG fluorescence from sellar dura, pituitary, and surrounding structures in 30 consecutive patients. Also we could distinguish sellar tumor from pituitary gland or stalk. There were no complications that resulted from the use of ICG or the fluorescent light source. ICG fluorescence endoscopy shows promise as an intraoperative modality that can help preserve the normal pituitary function while avoiding dangerous dissection which may contribute to further develop the fluorescence endoscopic resection technique.

(Received September 12, 2014 ; accepted October 16, 2014)

Key words : endoscopy, skull base, endonasal, ICG, fluorescence

Jpn J Neurosurg（Tokyo） $24: 85^{-91, ~} 2015$

\section{はじめに}

下垂体腺腫摘出にはじまった内視鏡単独経鼻的経蝶形 骨洞法は，いまや矢状面では前頭蓋底から頭蓋䅡椎移行 部まで, 冠状面では海綿静脈洞, 翼口蓋窩, 側頭下窩に 至るまでの到達が可能となり ${ }^{2)}$, 内視鏡下頭蓋底手術と いう新しい分野を切り開いた。しかしながら実際に手術 を行う際には周辺構造の的確な把握が必要であり, リア ルタイムに情報を供給してくれる支援システムの重要性 が痛感される。これまでにも頭部固定の必要がない磁場 式ナビゲーションシステムや, 経頭蓋超音波モニタリン グなどの有用性が報告されてきたが，近年では光学的画
像支援が注目されている ${ }^{1)}$. 内視鏡下手術においても, グリオーマなどの開頭術で用いられている 5-aminolevulinic acid（5-ALA）を松果体腫瘍の経脳室的内視鏡下 摘出術で用いた症例 ${ }^{8} や$, fluorescein sodium を投与して 軟性鏡下で脳室内を観察した症例 $\left.{ }^{3}\right)$ において有用性が報 告されている. Indocyanine green (ICG) は脳血管障害の 手術で汎用されており，血管 patency を確認するのに有 用であるが，経鼻的内視鏡手術での応用はまだ少ない4). われわれは経鼻的内視鏡手術を 500 例以上経験する中 で，2004 年からはトルコ鞍外の病変に対する適応を広 げ，いわゆる拡大蝶形骨洞法をこれまでに 90 例行って きた. 2013 年からは ICG を投与して観察できる内視鏡 

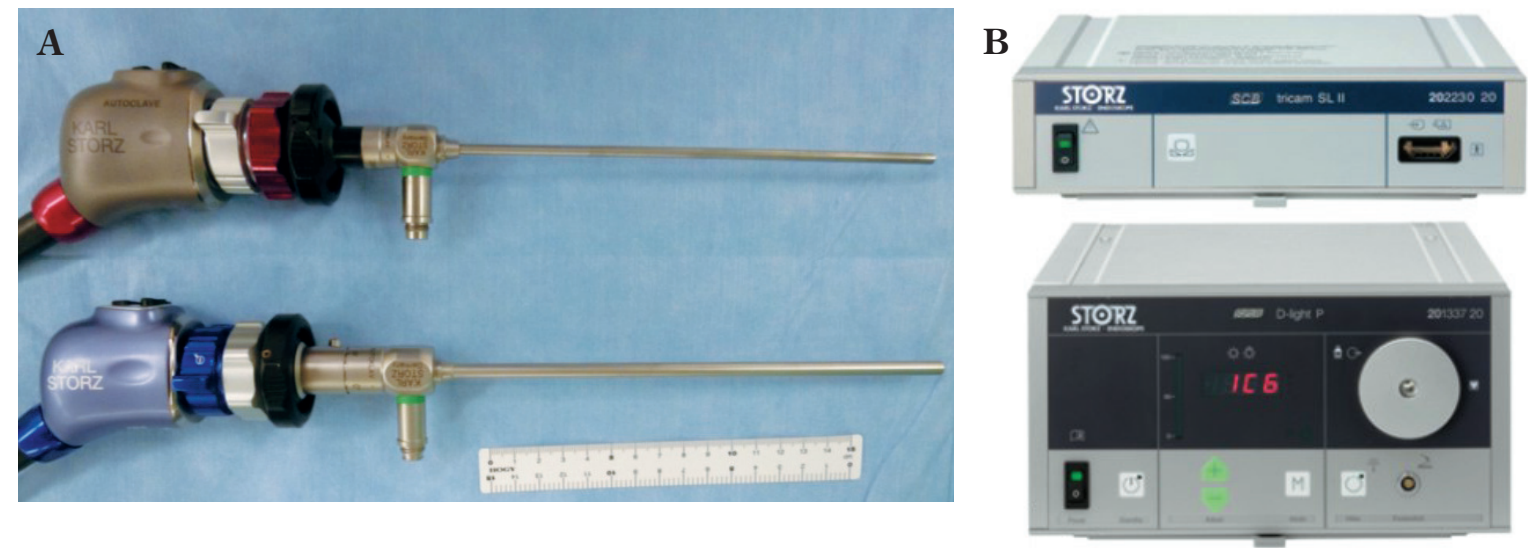

Fig. 1 Photograph of endoscopes and the ICG fluorescence system (KARL STORZ, Germany) A : Image $1 \mathrm{HD}$ scope (upper) and ICG fluorescence endoscopy (lower).

B : Endoscopy D-Light C system.

Table 1 Patient characteristics and observation timing of ICG fluorescence

\begin{tabular}{l|c|c|c|c|c|c}
\hline \multirow{2}{*}{\multicolumn{1}{c|}{ Diagnosis }} & \multirow{2}{*}{ Case } & \multicolumn{2}{c|}{$\begin{array}{c}\text { Surgical } \\
\text { approach }\end{array}$} & \multicolumn{3}{c}{ Timing of observation } \\
\cline { 3 - 7 } & & ETSS & E-ETSS & $\begin{array}{c}\text { Sellar } \\
\text { floor }\end{array}$ & $\begin{array}{c}\text { During } \\
\text { resection }\end{array}$ & $\begin{array}{c}\text { After } \\
\text { resection }\end{array}$ \\
\hline Nonfunc. adenoma & 15 & 13 & 2 & 8 & 3 & 6 \\
GH adenoma & 7 & 5 & 2 & 2 & 2 & \\
ACTH adenoma & 1 & 1 & 0 & 1 & 1 & 1 \\
Craniopharyngioma & 2 & 0 & 2 & & 1 & 1 \\
Meningioma & 2 & 0 & 2 & 2 & & \\
Chordoma & 1 & 0 & 1 & 1 & & \\
Dermoid & 1 & 0 & 1 & 1 & & \\
Rathke's cleft cyst & 1 & 1 & 0 & 1 & & 7 \\
\hline \multicolumn{1}{c}{ Total } & 30 & 20 & 10 & 16 & 7 & 8 \\
\hline
\end{tabular}

ETSS : endoscopic transsphenoidal surgery, E-ETSS : endoscopic endonasal transsphenoidal surgery
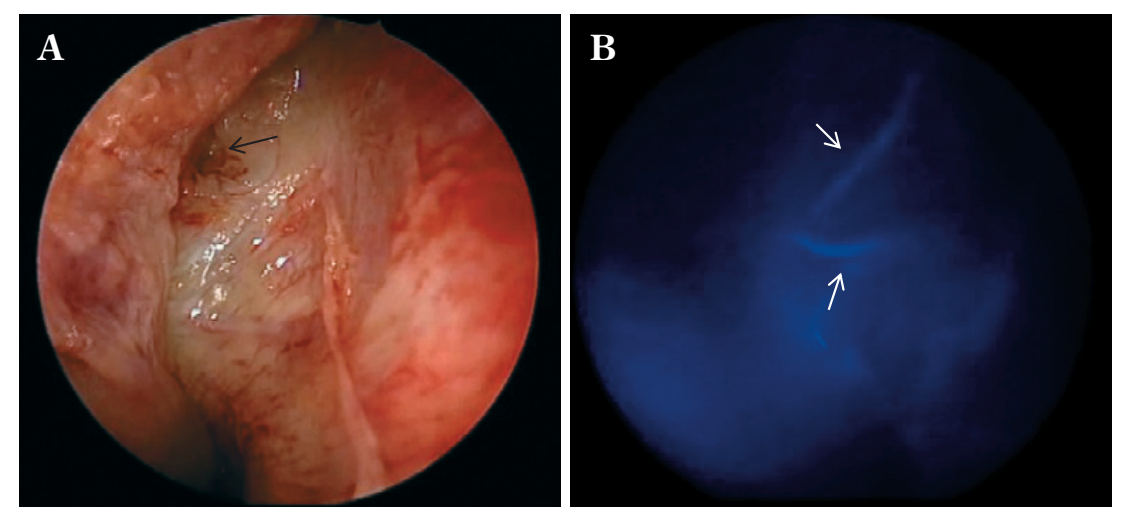

Fig. 2 Endoscopic observation of sphenopalatine artery

Observation of the right spheno-ethmoidal recess with white light (A) and ICG fluorescence (B). Black arrow in $\mathbf{A}$ indicates the sphenoid osteum. White arrows in $\mathbf{B}$ indicate the septal branches of the sphenopalatine artery. 

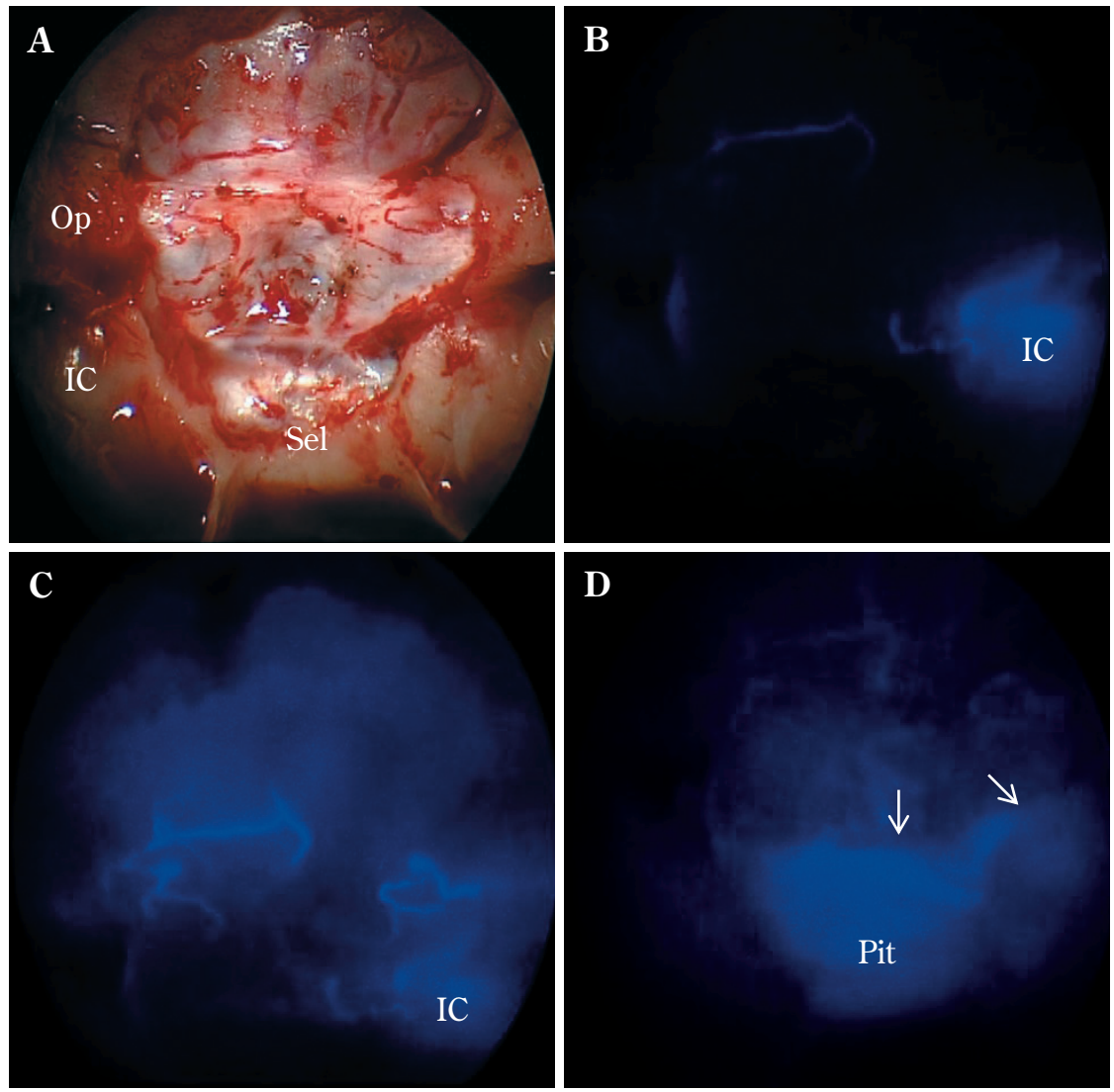

Fig. 3 Endoscopic observation of the sellar floor and surrounding structure

A case of a 33-year-old woman with tuberculum sellae meningioma.

A : The dura of the sellar floor, tuberculum sellar and frontal base were all exposed.

B-D : Photographs of ICG fluorescence endoscopy. B) The left internal carotid artery (IC) was recognized 30 seconds after administration of ICG intravenously. C) Five seconds after IC enhancement, microvessels were enhanced on the dural surface of the tuberculum sellae, which indicated tumor attachment. D) Fifteen seconds after IC enhancement, the pituitary gland was gradually enhanced. Both the intercavernous sinus and cavernous sinus (arrows) were enhanced prior to the pituitary gland.

Op : optic prominence, IC : internal carotid artery, Pit : pituitary gland

（ICG 蛍光内視鏡, KARL STORZ) を導入し手術中の観察 を行っている。われわれの初期経験で得られた有用性と 課題について検討する.

\section{ICG 内視鏡の使用方法と対象}

使用したシステムは，KARL STORZ Endoscopy DLight C system $(5 \mathrm{~mm})$, 励起波長 : near-infrared light $(805 \mathrm{~nm})$ ，蛍光波長： $835 \mathrm{~nm}$, telescope filter：passage $>=790 \mathrm{~nm}$ を装着したハイビジョン内視鏡である（Fig. 1)。スコープにはフィルターが内蔵されており，フット
スイッチで白色光と ICG 蛍光モードの切り替えが可能 である (Fig. 1A lower)。スコープには専用の洗浄器具が 装着できないので，通常の経鼻頭蓋底手術は別の Image $1 \mathrm{HD}$ システム（Fig. 1A upper）を使用している. ICG 観 察時にはシステムを切り替えたうえで, 生理食塩水 10 $\mathrm{m} l$ に溶解した ICG $25 \mathrm{mg}$ を $5 \mathrm{~m} l$ 経静脈的に投与し，直 ちに $10 \mathrm{ml}$ の生理食塩水を追加投与した。内視鏡は固定 して画像をビデオ撮影し, 術後に ICG 輝度の定量を行つ ている.

今回観察したのは経鼻頭蓋底手術を行った 30 例であ り，経蝶形骨到達法が 20 例，前頭蓋底の拡大を行った 

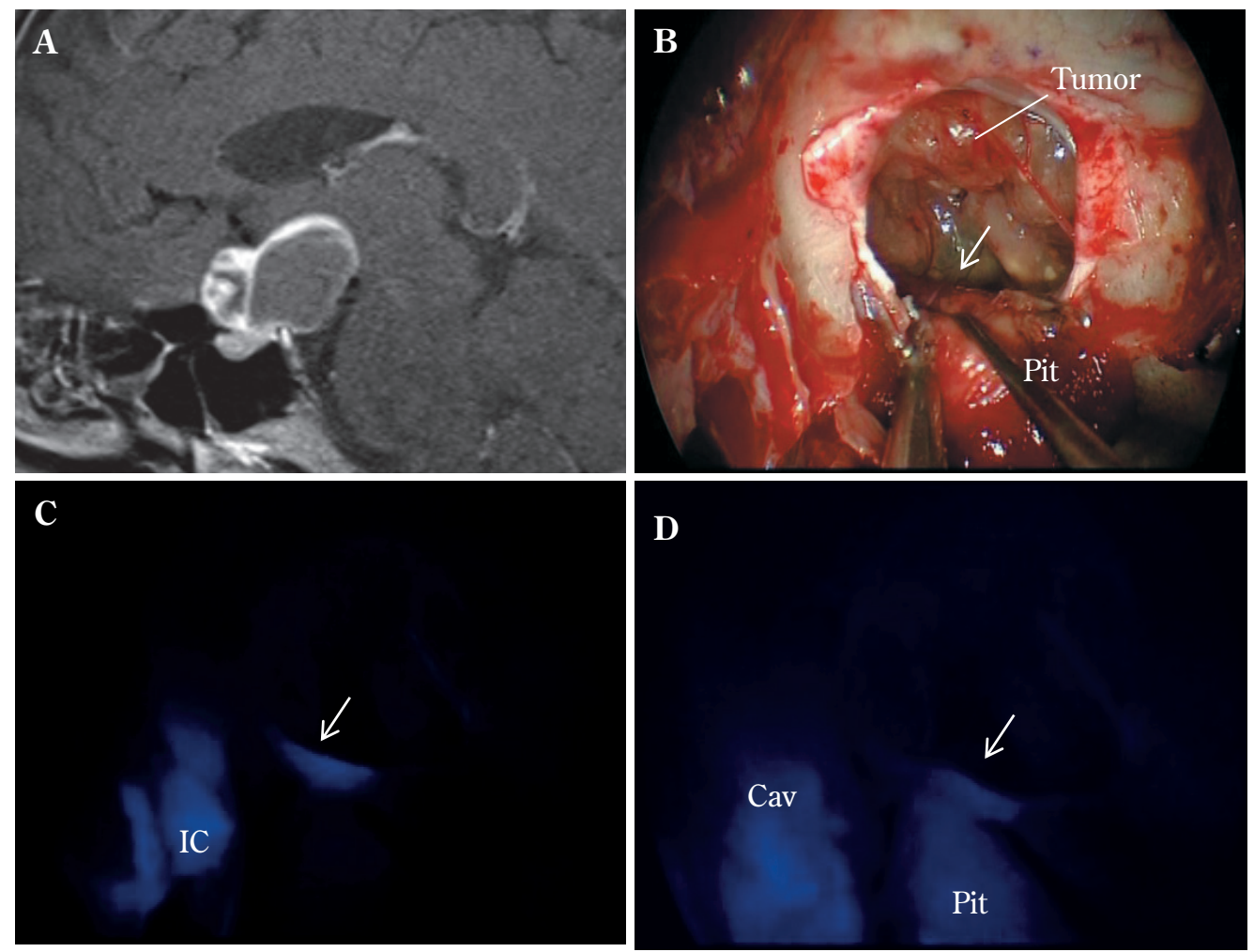

Fig. 4 Endoscopic observation of the pituitary stalk during craniopharyngioma resection

A case of a 42-year-old man with craniopharyngioma.

A : Preoperative MRI showed mixed type craniopharyngioma in the suprasellar region.

B : During tumor removal, the tumor cavity was exposed along with the pituitary gland (Pit) and the tumor capsule.

C : ICG fluorescence endoscopy revealed strong enhancement of internal carotid artery (IC) and pituitary stalk (arrow).

D : Several seconds after IC enhancement, the pituitary gland (Pit) with cavernous sinus (Cav) were enhanced. According to the findings by ICG endoscopy, the pituitary stalk was confirmed under white light (arrow in $\mathbf{B})$.

症例が 10 例であった。症例の内訳と観察のタイミング を Table 1 に示した。鞍底部までの観察は 30 例中 16 例 で行われた。摘出中に ICG 内視鏡に交換して観察したも のが 7 例, 摘出後の観察が 8 例であった. 成長ホルモン (growth hormone：GH) 産生腺腫と副腎皮質刺激ホルモ ン (adrenocortico hormone : ACTH) 産生腺腫の 2 例に 対しては, ICG 内視鏡を固定して蛍光観察下に摘出を 行つた.

\section{経蝶形骨手術における解剖学的指標の観察}

代表症例を示しながら観察のポイントを述べる。

鼻粘膜：右蝶形骨洞自然口の観察時に ICG を投与する と, 蝶形口蓋動脈の枝が描出された（Fig. 2). 有茎粘膜 弁の作成時に動脈の位置の把握が可能であり, 温存の指
標に有用と思われた。しかし，粘膜の厚さにより粘膜下 の動脈が観察できない症例もみられた。

鞍底部：トルコ鞍開空の際に, 両側内頝動脈の位置, 海綿静脈洞の位置が確認できた（Fig. 3)。内頝動脈は粘 膜を剝離したのちの骨外側から観察が可能であり，ICG 静脈内投与から 20〜30 秒で確認できた. ICG の輝度は 内頝動脈を覆っている頭蓋底部の骨の厚さにより左右さ れた。鞍底部では，内頝動脈，海綿静脈洞，下垂体，腫 瘍の順で描出された。内頝動脈の描出開始を 0 秒とする と, 海綿静脈洞は 5〜10 秒後, 下垂体は 15～30 秒後に 描出され，5 分以上持続した。

腫瘍摘出時における有用性：前頭蓋底拡大法を行う際 に, 鞍結節部で intercavernous sinus が明瞭に確認できた (Fig. 3D)，症例により明瞭であるものとほとんど描出さ れないものがあり，切開に際して予測可能であった。腫 

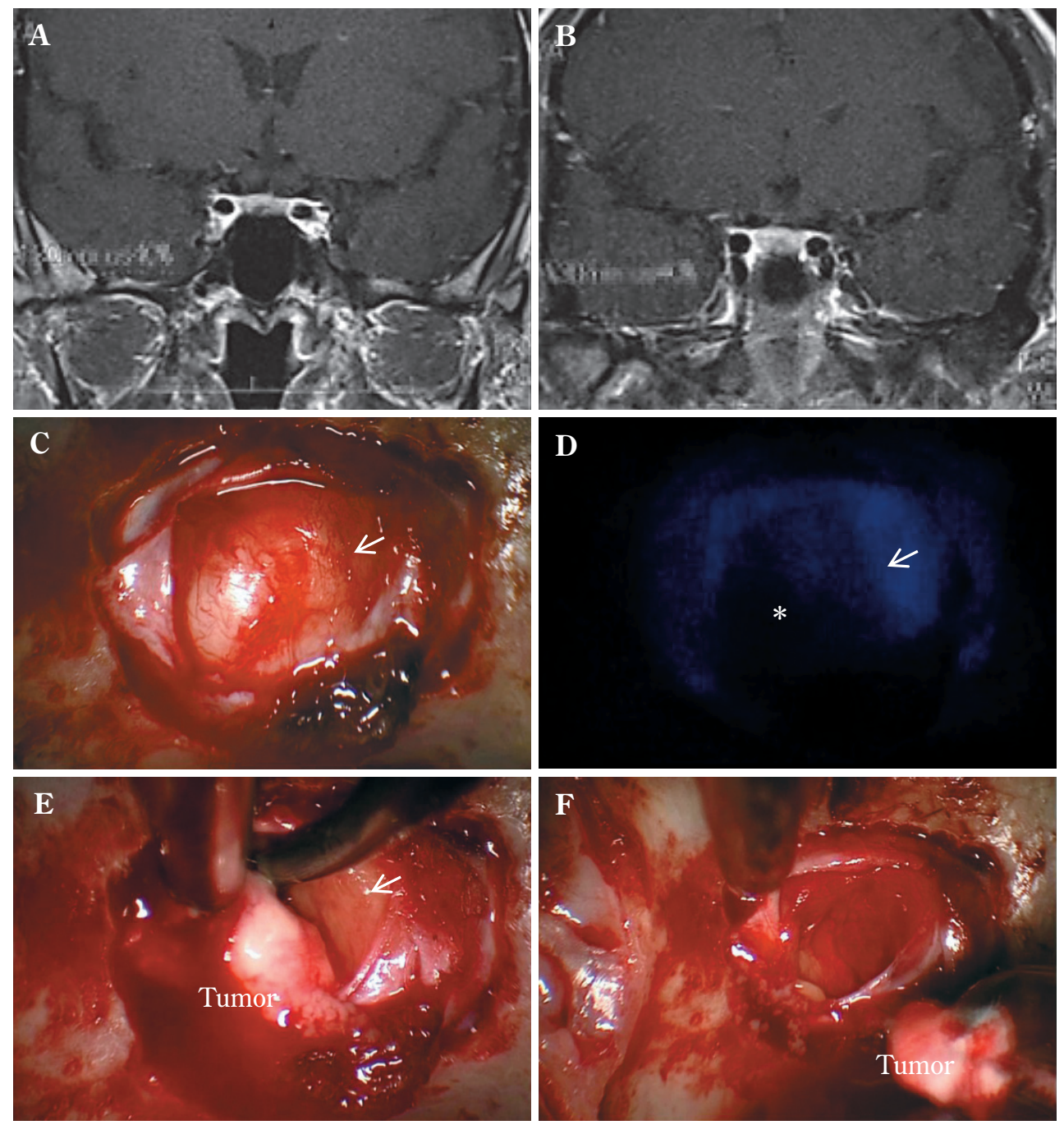

Fig. 5 Removal of an ACTH secreting pituitary adenoma with ICG fluorescent endoscopy

A case of a 34-year-old man with Cushing disease.

A, B : MRI dynamic images showed a less enhanced lesion in left side of the pituitary gland. The margin of the lesion was not clear.

C : Intraoperative endoscopic view of the sellar floor. The dura was opened and the pituitary gland was exposed. The edge of the tumor was not obvious.

D : After ICG administration, the pituitary gland exhibited normal enhancement whereas the tumor was less enhancement (indicated by asterisk).

E : The left side border of the tumor was incised.

F : The cavity after removal of the tumor showed normal pituitary gland.

The left side border point between tumor and normal gland is indicated by arrows in $\mathbf{C}, \mathrm{D}, \mathrm{E}$.

瘍剝離に際しては，下垂体茎の位置を確認できた。下垂 体茎は髄膜腫，頭蓋咽頭腫において腫瘍よりも明らかに ICG 信号輝度が強く, 容易に区別が可能であった（Fig. 4).ただし腫瘍内から視野内に露出されていないと判別 は困難であった。また下垂体腺腫摘出症例においては, 腫瘍は正常下垂体に比べ ICG 信号輝度が低く, 境界を区 別するのに有用と思われた（Fig. 5).
摘出後の頭蓋内血管：拡大法で腫瘍摘出を行った後の 視神経下面の観察において, Pcom. perforator や superior hypophyseal artery（SHA）の血流の確認，視神経表面の 血管の開通性の確認が可能であった（Fig. 6).

今回の観察結果を Table 2 にまとめた. ICG 蛍光輝度 の定量は現在行っているところであるが, 術者の主観で 観察された信号の程度を 3 段階で評価した。粘膜下の動 

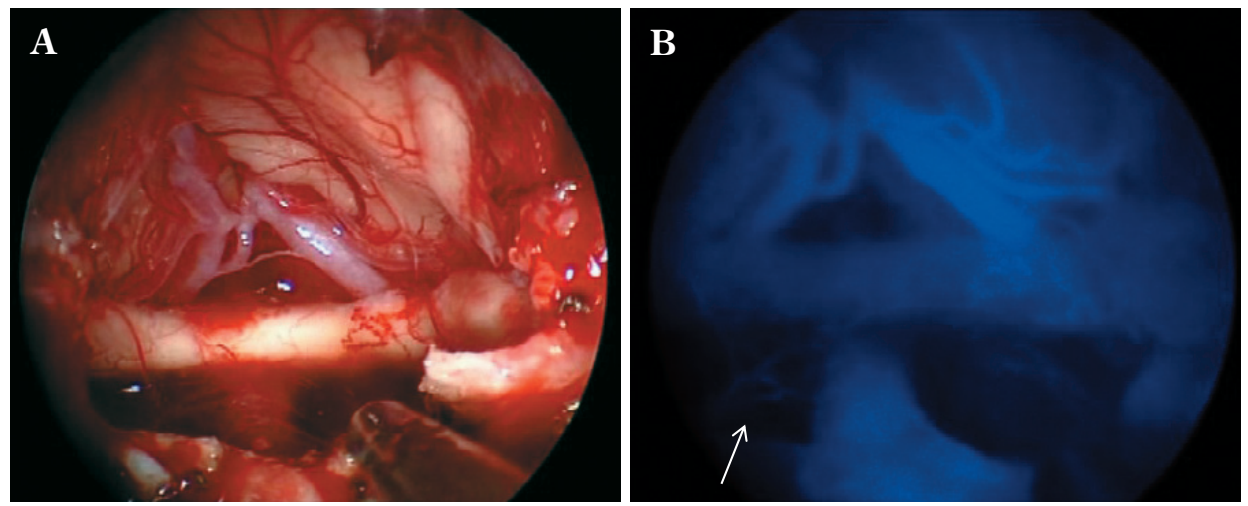

Fig. 6 Endoscopic photograph of a frontal base lesion

A case of a 44-year-old woman with tuberculum sellar meningioma. After removal of the tumor, the frontal base was observed by white light (A) and ICG fluorescence (B). The pituitary gland, stalk, optic nerve and anterior cerebral arteries were well enhanced. The enhancement of the right superior hypophyseal arteries was confirmed by ICG endoscopy (arrow in $\mathbf{B}$ ).

Table 2 Detection efficacy by ICG endoscopy

\begin{tabular}{|c|c|c|}
\hline Objects & Estimation & Remarks \\
\hline Vessels under the mucosa & $\triangle$ & Depend on the thickness \\
\hline Vessels under the bone & & \\
\hline $\mathrm{IC}$ & $\bigcirc$ & Depend on the thickness \\
\hline Cavernous sinus & $\triangle$ & Depend on the thickness \\
\hline Structures under the dura & & \\
\hline $\mathrm{IC}$ & (a) & \\
\hline Cavernous sinus & (a) & \\
\hline Pituitary gland & $\bigcirc$ & Depend on the depth \\
\hline Tumor & $\bigcirc$ & Depend on the depth \\
\hline Structures exposed & & \\
\hline Arteries & (a) & \\
\hline Perforators & (a) & \\
\hline Pituitary stalk & (a) & \\
\hline Posterior gland & $\bigcirc$ & Depend on the exposure \\
\hline
\end{tabular}

脈は表層にある症例では観察可能であったが，粘膜の肥 厚により観察できないものもみられた。鞍底部周辺の構 造は全例観察でき，硬膜外からは内頝動脈，海綿静脈洞 は全例で確認できた。硬膜内の血管や下垂体，下垂体茎 も描出が明瞭であった。対象とした下垂体腺腫と頭蓋咽 頭腫においては,いずれも正常下垂体よりも輝度が低く, 境界は容易に区別された。

\section{考 察}

内視鏡下での蛍光観察に関する報告は 5-ALA におい て散見される。グリオーマ摘出術において，顕微鏡下で
は観察できない部分でも内視鏡による強い光で検出がで きるため, 腫瘍摘出率が向上したという報告5)もみられ, その有用性が示されている。 今回投与した ICG は 5ALA とは異なり，血管内を流れる色素を検出するため, 細胞の代謝というょりも，細い血流が検出できる。また ICG は 5-ALA の 2 倍の 2 2.5 mm の厚さの組織を透過 することができる67)ことからも，5-ALA に相補的な手 段といえよう。

今回行った検討でも，ICG 内視鏡を併用することで， 肉眼的観察に加え血流という観点から構造を再確認でき る意義が大きいと思われた。たとえば内頝動脈の位置や 海綿静脈洞の広がりなど，通常の内視鏡下での観察では 
判断しにくい場合, 骨の開空や硬膜の切開を行う前に ICG 内視鏡で位置を確認することにより危険な切開を 回避することができた. また腫瘍と正常下垂体の区別や， 腫瘍内に埋没した正常動脈の位置なども術中に把握する ことが可能であり, 機能障害を起こさない安全な摘出に 寄与したと思わ机た。さらに Litvack ら ${ }^{4)}$ の報告と同様 に，われわれも有害事象は 1 例も認めなかった。 今後症 例を重ね，ICG 内視鏡を使用することにより長期的手術 成績が向上したかどうかの統計学的検証を行っていく必 要があると思われる。

一方, 深在性病変の観察は困難であり, 現時点ではあ くまでも肉眼的判断の確認としての用途に限られる。 た ICG の静脈投与開始から手術野での内頝動脈描出ま での時間は固体差があり, ICG の画面上の輝度は内視鏡 の位置で変わることも判明した. リアルタイムに定量で きるシステムを構築するには, 一定の条件を設定するこ とが必要と思われる.まずは ICG 投与後の各組織の描出 に対する時系列の客観的な違いを統計学的に証明するこ とが必要である ${ }^{4)}$ それをもとに，正常下垂体や下垂体 茎の染色速度から術後の機能予測を行う試みや, 深部の 微小腺腫を描出する方法の開発が今後の課題であろう.

\section{まとめ}

経鼻内視鏡手術において, 術中 ICG の投与による蛍光 観察は, 白色光での観察以上に多くの情報をもたらし, 安全な手術を行ううえで有用であると考元られた。今後 各施設での症例経験が重なるにつれ, リアルタイムの ICG 定量や観察された画像の調整などによる新たな情 報の提供が進んでいくものと期待している.
著者の COI（conflicts of interest）開示: 本論文の発表に 関して開示すべきCOI はありません。

\section{文 献}

1) Behbahaninia M, Martirosyan NL, Georges J, Udovich JA, Kalani MY, Feuerstein BG, Nakaji P, Spetzler RF, Preul $\mathrm{MC}$ : Intraoperative fluorescent imaging of intracranial tumors: a review. Clin Neurol Neurosurg 115: 517-528, 2013.

2) Kassam AB, Prevedello DM, Carrau RL, Snyderman CH, Thomas A, Gardner P, Zanation A, Duz B, Stefko ST, Byers K, Horowitz MB : Endoscopic endonasal skull base surgery: analysis of complications in the authors' initial 800 patients. J Neurosurg 114: 1544-1568, 2011.

3) Kubo S, Inui T, Yamazato K: Visualisation of the circumventricular organs by fluorescence endoscopy. J Neurol Neurosurg Psychiatry 75: 180, 2004.

4) Litvack ZN, Zada G, Laws ER Jr: Indocyanine green fluorescence endoscopy for visual differentiation of pituitary tumor from surrounding structures. J Neurosurg 116: 935-941, 2012.

5) Rapp M, Kamp M, Steiger HJ, Sabel M: Endoscopicassisted visualization of 5-aminolevulinic acid-induced fluorescence in malignant glioma surgery: a technical note. World Neurosurg 82 (1-2): e277-279, 2014.

6) Stolik S, Delgado JA, Pérez A, Anasagasti L: Measurement of the penetration depths of red and near infrared light in human "ex vivo" tissues. J Photochem Photobiol B 57: 90-93, 2000.

7) Stummer W, Stocker S, Wagner S, Stepp H, Fritsch C, Goetz C, Goetz AE, Kiefmann R, Reulen HJ : Intraoperative detection of malignant gliomas by 5 -aminolevulinic acid-induced porphyrin fluorescence. Neurosurgery 42 : 518-525; discussion 525-526, 1998.

8) Tamura Y, Kuroiwa T, Kajimoto Y, Miki Y, Miyatake S, Tsuji M : Endoscopic identification and biopsy sampling of an intraventricular malignant glioma using a 5-aminolevulinic acid-induced protoporphyrin IX fluorescence imaging system. Technical note. J Neurosurg 106:507-510, 2007.

\section{経鼻頭蓋底手術におけるICG 蛍光内視鏡の有用性}

矢野 茂敏 秀 拓一郎 篠島 直樹 倉津 純一

経鼻的頭蓋底手術はその適応が拡大していくにつれ，手術の安全性と確実性を担保する術中の画像 支援システムへの期待が高まっている. その中で注目されるのが indocyanine green (ICG) 蛍光内視 鏡下観察である. 今回, 経鼻頭蓋底手術において, ICG 蛍光内視鏡（KARL STORZ 社）による観察を 行った 30 例の結果をまとめた. 内頝動脈や蝶形口蓋動脈などの頭蓋底構造の確認, 硬膜外からの海 綿静脈洞の範囲の推定, 腫瘍と正常下垂体の区別が可能であった. 一方, ICG 内視鏡の位置や出血の 状況により描出感度が違うことも明らかとなり，定量には一定の条件が必要と考えられた，本方法は 安全性が高く有用であり, 今後の治療成績向上へ寄与することが期待される. 